\title{
Title: Elementary School Students' Perceptions of school library and expectations of Library Space
}

\author{
Lin-jen Huang \\ graduate student \\ National Taiwan Normal University \\ Graduate Institute of Library \& Information Studies \\ Taiwan \\ Jiann- cheng Shieh \\ Associate Professor \\ National Taiwan Normal University \\ Graduate Institute of Library \& Information Studies \\ Taiwan
}

\begin{abstract}
This study main research purposes were to explore elementary school students' perception of school library, understanding elementary school students' experience of school library use and explore elementary school students' ideal library. Data for this study have been collected chiefly through semi-structured interviews and analysis of drawings. This study was targeted at mid-grade and high-grade students of elementary school. It is expected that understand the students' perception of library and provide a suggestion for improving library space.
\end{abstract}

Elementary school student; perception of library; idea library

\section{Introduction}

Students spend most of their time at school, so the school library is the one they visit the most. To encourage school children to make use of library, school library has to provide sufficient library resource, good reading environment, well-trained reading instructors and enough funds. Development of reading environment in libraries is the priority; designing an interesting and attractive environment where children are willing to enter will then lead them how to use library resource. The first impression on library is one of the major factors to affect children's feeling to library. However, how to build a library that children are fond of? This issue should be dealt with by taking children into consideration.

In Taiwan, the subjects of elementary school library studies were most refer to development of library or status of library such as software and hardware equipment of library, the library service item, library education, Library automation situation, information literacy, and the problem about library management. There were less concerned with library building and the experience or feelings of user usages. Besides, the investigate target are often to administrative staff or librarian, not regard to students. But library user education in elementary school is the most basic of school library education. To practice school library education for students, we not only need to know the perception of library of students, should understand their views and expectation on the library, then the library design will close to 
students ' demand. If shorten the gap between student's needs and expectations toward the library and the real school library service, the students may like to use library more.

This research mainly explores elementary school student' perception of school library and their needs to the library space, so this study main research purpose is:

1. Explores elementary school students' perception of school library.

2. Understand elementary school students' experience of school library use.

3. Explore elementary school students' ideal library.

Because of above research purpose, the research question of this research is as follows:

1. What is the perception toward school library of elementary school students?

2. What kind of channel do the elementary school students get about the library concept?

3. What kind of service do elementary school students use in the library?

4. What feeling and perception of library use do elementary school students have?

5. What are the expectations of school library by elementary school students?

6. What a idea school library in elementary school students' mind?

\section{Literature Review}

For children's service, Sannwald provide several key points of general design considerations: (1)The library space needs to attract and invite children to visit. (2)The interior scale of the children's space does not make children feel intimidating or oppressing, the ceiling levels must to be appropriate and the height of the book stacks and furniture needs to consider the children of all ages. (3)The different lighting levels and fixture types in children area would create a comfortable and cozy atmosphere and encourage reading. (4)An interesting and exciting display area can let children have an opportunity to show their own art work in the library, and a great opportunity to promote the library collections. (5)The craft area is a very important area for children of different ages. The dirty mark on the furniture and floors must easy to clean. (6)The family reading area can offer rocking or oversized chairs to allow parents to put children on their lags for reading stories. (7)Plan the media and electronic workstations for children (Sannwald,2007).

When the library draw up a proposal regarding a new program for children, aside from looking into subject related references, actual experiences working with related specialist and researchers, we should invite children and youth participate in the group planning. For example U.S.A. university of Maryland established an interdisciplinary team of researchers to work with seven children (ages 7 to 11) to design new digital library. The children can contribute their ideas and suggestions for digital library system and discussed with adults(Druin,2005); Another case like Aarhus public library of Denmark, in the cause of building a new library for children they hold an activity and invite 9 to 13 year old children to utilize the existing material to create a library model with their imagination (Helene,2007); In order to understand the library user uses satisfaction and any improvement to propose, Fisher got information from teenagers through questionnaire interview (Fisher,2003); The Denver children's library of U.S.A. spent three years to observe children's behavior in the library and the usage of the library, there were several problems in library space and arrangement of furniture. For a better service, the library invited children(under the age of 10) to discuss together and share their ideas of the perfect library which they think. These opinions reference as library space planning in the future (Sandlian \& Walters 1991). While real listening to children what suggestion and hope of the library for them, we can just know the drop between the adult's design and children experience of library use.

In order to understand children's needs and expectations to the library, the researchers usually collect data and gather related materials through various research methods such as 
questionnaire survey, interview, observation, drawing or other methods. Recently, there were two studies of elementary school library in Taiwan regarding what are students' favorites in the library and what is the appearance library they dreams of. As Kun-Yu Lai study, he adopted the qualitative research in a semi-structured in-depth interview and a participant observation research. He found that "the function of the school library lies not only on reading, circulating and searching, but also being a place for leisure and social activities." Students hope the library is a full fun and humorous place that offer very much comic books, computer, games etc....The environment also needs to be comfortable and enjoyable(Lai,2007). And in Tan-Yi Wang study, She used varied of methods including content analysis, participatory observation, constructive observation, environmental observation, semi-constructive interview, and children's painting analysis to collect the data. The dream library of student image is: (1)A neat, beautiful, comfortable environment with the pure and fresh air and it make users relax to reading. (2)The furniture and interior design is full of a variety of colors, sizes, and shapes. (3)Have a personal activity space with facilities, such as bed, computer, TV, etc... (4)Hi-Tech and convenient service, for example set up a passageway like slide, serve robots, etc... (5)Expect to be able to raise pets. (6) Have a restaurant and playing field (Wang,2007).

In a literature review, the researcher can found children have various imagination and suggestions to the library, these ideas are always very interesting and fancy. In this study, the researcher also want to know what a school library design is student's preference? Are there any differences and similarities between mid-grade and high-grad elementary school students? One of the purposes of this study include exploring student's school library of dreams.

\section{Method}

\section{Study Approaches}

Data for this study have been collected chiefly through semi-structured interviews and analysis of drawings. The semi-structured interview approach allowed children to speak out their true feelings about libraries. Questions were aimed at schoolchildren's impressions and ideas about libraries, their experiences with libraries, sources or channels through which they had learned about libraries, and their expectations of libraries, in order to understand their perceptions toward libraries. Simultaneously, as an attempt to acquire more complete and richer data, this study has also adopted the drawing analysis approach, setting "My Ideal Library" as the drawing theme and asking the children to sketch out what they thought a good library should be like, to supplement what they were unable to express with words during interviews.

\section{Study Samples}

This study was targeted at mid-grade and high-grade students with experience of using the elementary school library. Teachers, volunteered workers, staff members, administrators and schoolchildren without experience were excluded. At the same time, since children with mental or physical handicaps would involve special considerations, they were also left out. By purpose-stratified sampling one class from each grade between the fourth grade and the sixth grad was selected to provide study samples. Data collection was carried out in two stages. The first was to request the students of two classes to draw the ideal library in their minds. 61 drawings were collected. The second stage was the interviews 8 students randomly 
chosen from two classes (one class is the fourth grade, the other class is the sixth grade)and interviewed. (Table 1 and Table 2 show study sample statistics.)

Table 1 Sample of Drawing

\begin{tabular}{ccccc}
\hline Grade & boy & girl & Subtotal & Total \\
\hline 4 & 17 & 15 & 32 & 61 \\
6 & 16 & 13 & 29 & \\
\hline
\end{tabular}

Table 2 Sample of Interview Objects

\begin{tabular}{ccccc}
\hline Grade & boy & girl & Subtotal & Total \\
\hline 4 & 2 & 2 & 4 & 8 \\
6 & 2 & 2 & 4 & \\
\hline
\end{tabular}

\section{Results}

\section{Elementary School Student's Perceptions toward the School Library}

From the perspective of these schoolchildren, the function of a library was providing the environment for studying and relaxation. It was a place to visit to increase knowledge, look for information, borrow and return books, and explore unknown subjects. These children were also aware that a library had bookshelves, categorized extracurricular reading materials and picture books, bookmarks, desks and chairs, and a service counter. A small proportion of students had a deeper impression of the computers, printers, librarians, and direction signs. When inquired whether they remembered any activities conducted in the library, none of them could name a specific event, or simply had no idea. Yet when one of the activities was mentioned (a prize quiz, for instance), the children expressed that they had participated in that and were able to roughly describe the activity. This was probably due to that these schoolchildren had not been aware that the library had been responsible for the activity and having attended was their only memory.

\section{Sources of Elementary School Student's Awareness of Libraries}

During interviews, most schoolchildren confirmed that their parents had taken them to a public library before they started elementary school. Some of them had visited the school library with classmates. When asked how they had found out about the library in school, some students answered that other people had told them about the library and so they started to use it, for example: "During the first grade, the teacher had scheduled reading hours and taken us to the library." "On the first day of the orientation, the teacher had told us about the library." "During the first grade I didn't know the school had a library because it was in the basement. I found out about the library in second grade. My cousin was in first grade and she told me about it." "I asked my older brother what facilities an elementary had and he mentioned library." Two of the students interviewed came across the library when they were familiarizing themselves with the new environment and decided to check it out. They did not get the information from other people. One of them made the comment, "Oh, I saw it. There was a sign. So I just went in with my classmate." Quite the contrary, there was also a student who had never been to a library. He related that he had been aware of this place called library during the first grade but had never gone in until the teacher mentioned certain activities 
related to the library. He said. "I knew there was a library but I only passed by it and never went in. Later the teacher told us about a raffling event. So I went in there and discovered there were a lot of books that I would like to read."

With all the above combined, it is evident that the notion about the library mainly comes from revelation and introduction by parents, siblings, and teachers at school. Most elementary school children have had the experience of using a public library during kindergarten and are therefore no strangers to the school library. However, some schoolchildren have never had any contact with libraries and are not particularly interested, as a result. These children need guidance to learn to use the library. Therefore, the interpersonal network is an information channel that can play a rather significant role in helping children learn to use libraries.

\section{Elementary School Student's Current Use of the School Library}

Interviews with the eight students showed that activities schoolchildren undertook in the school library included reading, borrowing and returning books, drawing and painting, doing homework, and occasionally attending events held by the library. They usually went to the library during the reading class or between classes. Some students expressed that breaks between classes were too short and the library was closed after school; therefore, they did not use the library often. These students commented, "The library is never open when I have time." These interviews also revealed that the higher grade the students were, the less frequently they used the library. Before the $4^{\text {th }}$ grade, they have a reading class, so they use the library more often. By the time they were in $5^{\text {th }}$ or $6^{\text {th }}$ grade, they stopped visiting the library regularly. They had more schoolwork to tend to or had shifted their interests in other things, such as ball games. As a consequence, senior students did not use the library as frequently as their junior fellow students. In addition, the number of activities taking place in the library was also another factor that had an effect on students' use of the school library. Some students pointed out, "There used to be more activities. Now that nothing much happens there, plus I'm busier; I don't go (to the library) as often."

\section{Elementary School Student's Perceptions toward Using the School Library}

These students didn't seem to have developed any particular sentiment toward using the school library from their experiences. For some students the library was a quiet, convenient (they can read or check out books they are interested in,) and fun place, while others regard it boring to be there. Some students, for instance, feel, "Elementary school kids are not that interested in books." Only the ones who were fond of reading were attracted to the library: "It's a great place because there are lots of books and I enjoy reading." The students were also requested to compare the school library and public libraries. The results indicated that most students preferred public libraries for their spaciousness, better facilities and bigger collections. The lighting was also better and there were more seats. Few students liked the school library more because it was in the basement and therefore quieter. The attitude of the librarians also played a part in this. Some students expressed, "I prefer going to the school library. The people in there are more friendly and the service is better!"

\section{Elementary School Student 's Expectations of the School Library}

Longer Opening Hours Most schoolchildren visited the library during their reading class, between classes or after school. But the break between classes only lasted 10 minutes and the library was closed after school. Schoolchildren found it inconvenient and therefore hoped the library could extend its opening hours. 
Collections When the children were asked if they would visit the library more often if the opening hours were extended, some responded, "Probably not. There aren't that many books there." Other said straightforwardly that the school library did not have enough books and they often were unable to find information they needed: "They don't seem to have enough books... There is nothing on Chinese calligraphy. I'm learning Chinese calligraphy." There were also students who thought the books in the school library were tool old and that could reduce students' interest in using the library: "All the books are old. I don't feel like going in there. I'll just buy the books I want to read." Apparently, these students thought the library should improve and regularly renew its collections, maintain the completeness of books, and keep them clean.

\section{Space and Facilities}

(1) Hardware Reinforcement: The library was not equipped enough. Apart from books, it lacked computers, printers and enough seats. When asked what facilities the library should enhance, the children replied, "Printers are important, too. If someone without a library card is unable to finish reading something, they can print it out. Or, some people get dizzy when reading books. If they can print out the information $t$ in sheets, reading will be easier to read." "There should be computers for us to look for some information." "There should be a notebook computer at each seat." Some students expressed, "There should be one more counter for us to check out and return books. The counter is too small and it can get pretty crowded." This showed the students thought the counter space and the service staff were inadequate. It was slowing down the process of borrowing and returning books and creating human traffic jams.

(2) Appropriate shelf heights: Some students complained that the bookshelves were too tall and made it difficult to get some books sometimes. Some students suggested, "The bookshelves can be classified. Higher shelves are for senior students, while lower ones are for students in lower grades.

(3) Insufficient lighting: Lighting was another area the students thought needed improvement. For example: "The lights...I don't think are bright enough, not like in an Eslite Bookstore. There should be downlights or other lights that give a lot of light."

(4) Barrier-free facilities: Some students were concerned about the handicapped and thought the library should take handicapped people into consideration: "There should be facilities for blind people, such as offering information they can just listen to. Handicapped people can sit on a magic carpet to move at will and find books by themselves."

(5) Eating and drinking in the library: The children were aware that current regulations forbade eating and drinking in the library but still hoped they could have food and beverages in there: "What I really mean is if beverages and snacks are available in there, students will be more interested in coming here to study."

Incentive Measures Giving incentives could motivate schoolchildren to use the library. A student described the reason why he had enjoyed going to the library before: "There was a card to keep your reading record. After filling up a certain number of cards, you would be given an award certificate. I used to visit the library to borrow books between classes. The more I checked out, the more award certificates I got." "I like raffling because I could get presents." There were also ideas like: "If a student is given a piece of candy every time he or she goes to the library to study, everybody will be encouraged to visit the library more often."

Librarians These schoolchildren thought there should be people in the library to offer 
assistance at any time, especially students in lower grades: "Librarians can walk around and see if anyone needs help." "Librarians should help those who are not familiar with the library. Students in lower grades could always use some help."

Environmental Beautification From the interviews it was evident that girls were more concerned about the appearance of the environment. A student expressed, for example: "The resting area could use some flowers and decorations and the children's area should have some cuter, fashionable decorative items." Some students thought having more green plants would be good for health: "Plant some trees and make it like we're in the forest." "I hope I can see green trees the minute I step out the library. It will be good for eyes." But there was also a student who did not care about the subject. He said he did not particular notice how the surroundings were furnished. What mattered to him was whether the library had the books he wanted.

Exhibition Space Some students thought the library should make space to exhibit artworks by students, for instance: "The works from our art class or the cards we make for Mother's Day or Father's Day can be hung up to show to everybody." Other students had different opinions: "The library should carry other people's journals for our fellow students to read."

Separated Areas for Different Grades Same as the results from other studies, senior students asserted that their space should be separated from that of junior students. When schoolchildren talked about the advantages of public libraries, they mentioned separation of space for adults and children was a good idea: "(In the adult area) it is quiet and people can rally study, whereas children would just be shouting back and forth without thinking for others." There were also students who thought senior students didn't have the need to use the library, so the space could just be left for junior students: "Students under the $4^{\text {th }}$ grade take their reading class in the library, but senior students probably already have a lot of books in their classrooms so they can just read in the classroom."

\section{The Ideal Library in Elementary School Student's Minds}

Drawings of the ideal library proved that schoolchildren were in fact not at all impractical in their ideas of what a library should be like. Most designs described what the school library currently lacked, such as computers, printers, the food and beverage zone and the multimedia area. As for the collections, most children specifically emphasized the "comic book" category and "computer game guides" to express their need of recreation. Some other children included air conditioners in their drawings; obviously hoping it could be cooler in the library. 


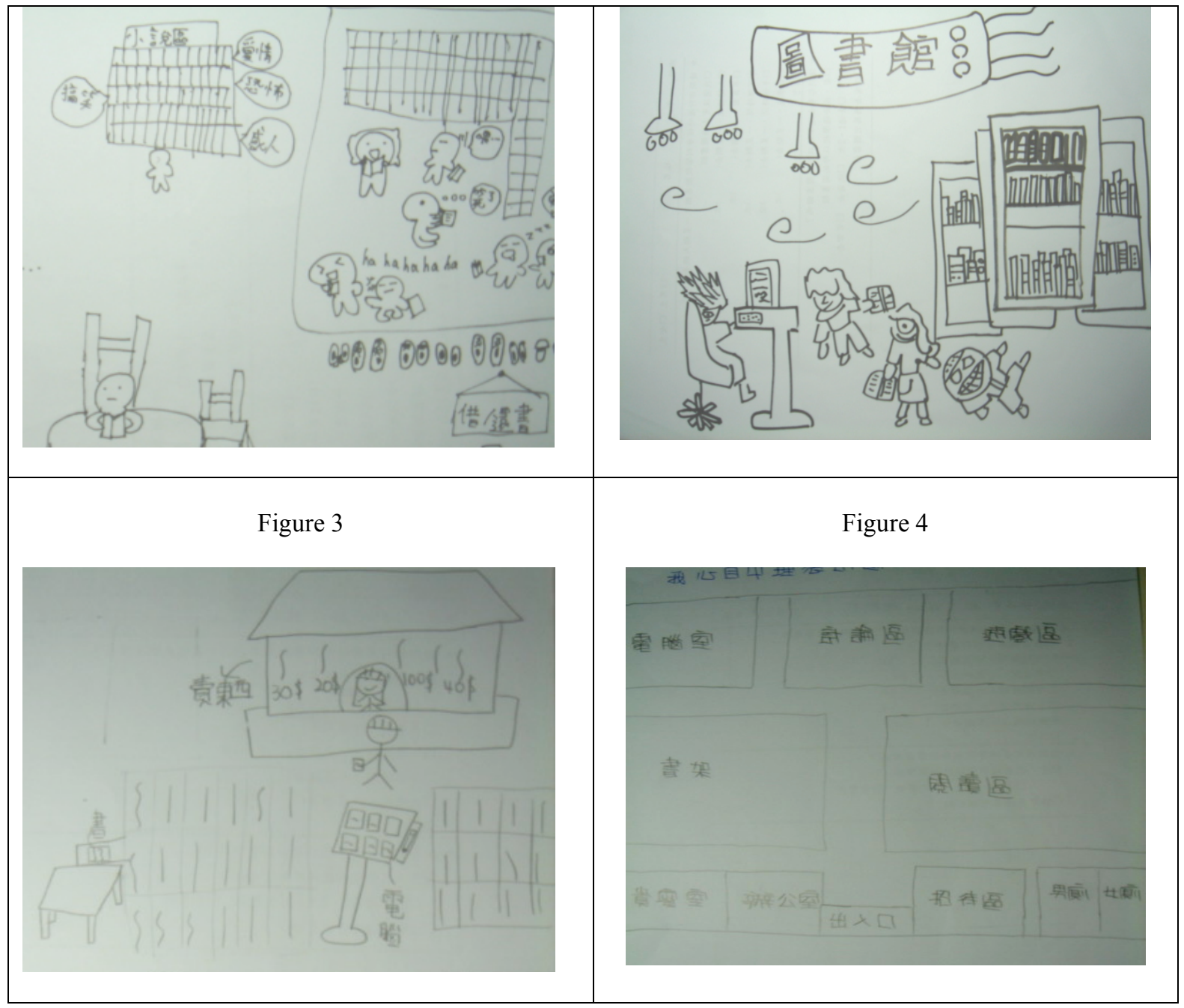

When divided according to their grade and gender, senior schoolgirls were noticeably more considerate and wanted to make sure other people could have their space, such as the offices, the reception room, the VIP room and the parent-child reading area. Junior students were more concerned about their own space and the room required for their interests, such as a handicraft area, a stationery area, a performance area, a swimming pool, a running track, etc. All students concurred on the necessity of basic library facilities, like the book area, the reading area and the service counter, Wooden floors also appeared in some of the drawings, probably because the school had specifically planned the "wooden floor" activity space and the students appreciated the idea. (Table 3 shows statistics of numbers of times various areas appeared in the drawings."

Table 3 Statistics of numbers of times various areas appeared in the drawings

\begin{tabular}{lccccc} 
& $\begin{array}{c}\text { Grade } \\
\text { (32 figures) }\end{array}$ & \multicolumn{2}{c}{$\begin{array}{c}\text { Grade } 6 \\
\text { (29 figures) }\end{array}$} & $\begin{array}{c}\text { All students } \\
\text { (61 figures) }\end{array}$ \\
\hline $\begin{array}{c}\text { Library space } \\
\text { allocation }\end{array}$ & $\begin{array}{c}\text { Boy } \\
\text { (17 figures) }\end{array}$ & $\begin{array}{c}\text { Girl } \\
\text { (15 figures })\end{array}$ & $\begin{array}{c}\text { Boy } \\
\text { (16 figures) }\end{array}$ & $\begin{array}{c}\text { Girl } \\
\text { (13 figures) }\end{array}$ & $\begin{array}{c}\text { Total } \\
\text { appearance } \\
\text { number of each } \\
\text { area }\end{array}$ \\
\hline Stack Area & 12 & 12 & 10 & 12 & 46 \\
\hline Reading Area & 6 & 8 & 6 & 8 & 28 \\
\hline Computer Room & 3 & 3 & 5 & 5 & 16 \\
\hline Entrances/Exits & 2 & 0 & 6 & 7 & 15 \\
\hline
\end{tabular}




\begin{tabular}{llllll}
\hline Circulation & 2 & 3 & 5 & 3 & 13 \\
\hline Restaurant & 2 & 2 & 3 & 4 & 11 \\
\hline Audiovisual & 2 & 1 & 3 & 2 & 8 \\
\hline Wooden Floors & 1 & 4 & 2 & 0 & 7 \\
\hline Restroom & 1 & 0 & 2 & 1 & 4 \\
\hline Shoes Cabinet Area & 0 & 2 & 1 & 1 & 4 \\
\hline Game Area & 1 & 0 & 1 & 2 & 4 \\
\hline Office & 0 & 0 & 1 & 2 & 3 \\
\hline Lounge & 0 & 0 & 1 & 2 & 3 \\
\hline Copy Room & 0 & 0 & 1 & 1 & 2 \\
\hline Arts/crafts Area & 1 & 0 & 0 & 0 & 1 \\
\hline Discussion Room & 0 & 0 & 0 & 1 & 1 \\
\hline Reception Room & 0 & 0 & 0 & 1 & 1 \\
\hline VIP Room & 0 & 0 & 0 & 1 & 1 \\
\hline Bulletin Board & 0 & 0 & 0 & 1 & 1 \\
\hline Family Reading Area & 0 & 0 & 0 & 1 & 1 \\
\hline Stationery area & 1 & 0 & 0 & 0 & 1 \\
\hline Activity Area & 1 & 0 & 0 & 0 & 1 \\
\hline Book Displayer & 0 & 1 & 0 & 0 & 1 \\
\hline Swimming Pool & 0 & 1 & 0 & 0 & \\
\hline Running Track & 0 & 1 & 0 & 0 & 1 \\
\hline Fountain & 0 & 0 & 0 & 1 & 1 \\
\hline $\begin{array}{l}\text { Only draw the } \\
\text { library building not }\end{array}$ & 4 & 3 & 4 & & 1 \\
shown inside & & & & & 1 \\
\hline
\end{tabular}

As for activities carried out in the library, aside from borrowing and returning books, some students also depicted people sleeping, swimming, watching movies, using computers, reading lying down, reading on chairs and buying food in the library.

Only in 12 out of all the drawings the library building was actually depicted and each one varied to a certain extent. A student imaginatively gave it the appearance of a library built in outer space (see Figure 5). There were also a castle-like structure (see Figure 7), a tree house (see Figure 8), and an individual house (see Figure 8). The architecture styles were quite different.

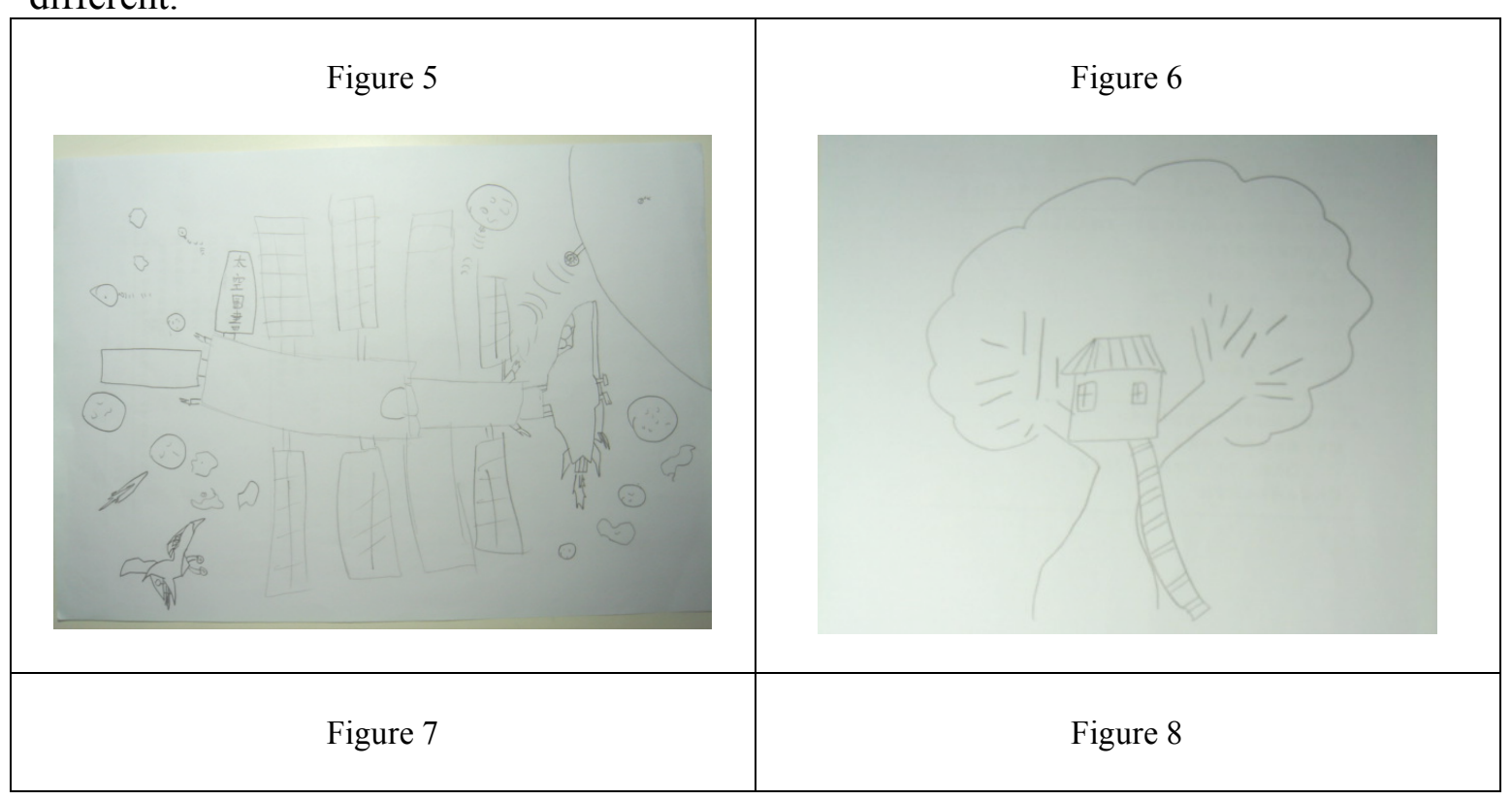




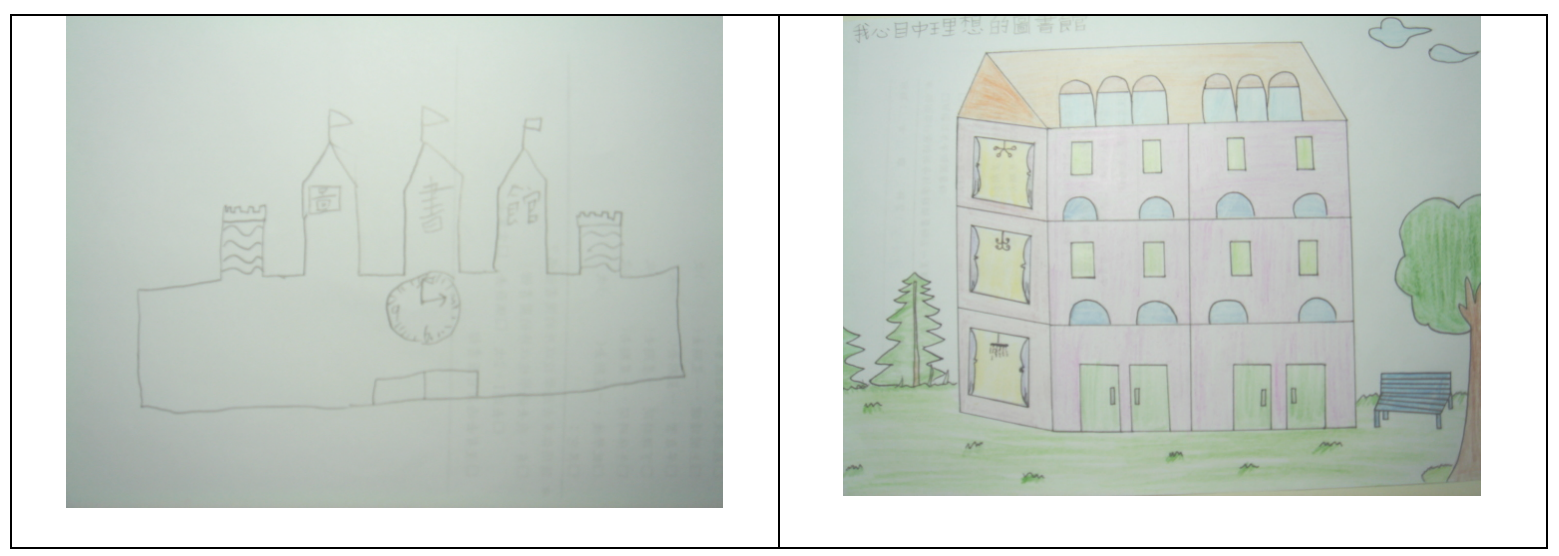

\section{Discussion}

Data from the interviews and drawings showed that most schoolchildren had already had a basic concept about libraries. They were aware that a library was a place where they could read, borrow and return books, look for information and have certain recreation. The fact that some children had had their experiences with libraries before they started school signifies that some parents consider it important for their children to learn to use libraries at a young age. The schoolchildren's experiences with the school library didn't seem to make them very interested in it or expect much from it and they were not very clear about activities that had taken place in the school library. The interviews revealed that these schoolchildren did remember the activities they had attended but didn't know that the library had been responsible for these activities. They also thought giving incentives could motivate students to use the library. However, the more senior students were, the less frequently they used the library. The reason was, besides not having enough time during class breaks and the library's insufficient collections, senior students seemed to have developed a passive attitude toward the library. When they no longer had the reading class in the library with guidance from a teacher, students stopped visiting the library regularly.

In comparison, investigation of schoolchildren's expectations and opinions toward libraries in this study is more focused on the practical aspect, unlike in the Danish Aarhus Public Library case and the thesis by Wang Tan-Yi, in which the objects of experiment had a more entertaining and dreamlike imagination for libraries. The difference may have been caused by the environmental variation, the confidence the researched had in the researcher, the researcher's experience, analytical technique and differentiation in study samples. To perfect the content of research, the author of this paper will conduct further study in the two following directions:

1. More schoolchildren should be interviewed and the questions should be extended both in range and depth in order to obtain more detailed and richer data.

2. Results of interviews can be regarded as initial investigative achievements. A questionnaire based on the quantitative research approach should then be designed to survey schoolchildren's awareness and expectations of libraries. In the end, quantitative and qualitative data should be sorted out and arranged to produce a more complete report.

\section{References}

Wang,Tan-Yi (2007). The Evaluation Study of Using and Planning of Elementary School Libraries.Unpublished master's thesis, National Taiwan Normal University, Taipei. 
Lai,Kun-Yu (2007). Motivations and Influential Factors of the Students' Usage in the Taipei Municipal Mingchuan Elementary School Library. Unpublished master's thesis, National Taiwan University, Taipei.

Druin, A.(2005). What children can teach us: developing digital libraries for children with children. The Library Quarterly, 75(1), 20-89

Fisher, H.(2003). A Teenage View of the Public Library: What Are the Students Saying? Australasian Public Libraries and Information Services, 16(1), 4-16.

Helene B.(2007). Experimentarium ... aka fun. Retrieved October 17, 2007, from http://www.librarybytes.com/2007/10/experimentarium-aka-fun.html

Sandlian, P. \& Walters, S.(1991). A Room of their Own: Planning the new Denver Children's Library. School Library Journal, 37(2), 26-29.

Sannwald, W. W.(2007). Designing Libraries for Customers. Library Administration \& Management, 21(3), 131-138.

\section{Statement of Originality}

This statement certifies that the paper above is based upon original research undertaken by the author and that the paper was conceived and written by the author(s) alone and has not been published elsewhere. All information and ideas from others is referenced. 